\title{
QUANTIFICATION OF THE TERRESTRIAL PHYTOMASS AND CARBON IN THE MOUNTAINOUS FOREST ECOSYSTEM USING REMOTE SENSING AND IN-SITU OBSERVATIONS
}

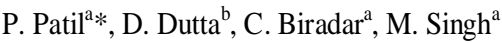 \\ ${ }^{a}$ International Center for Agricultural Research in the Dry Areas (ICARDA), Jordan (P.Patil, M.Singh and C.Biradar@cgiar.org) \\ ${ }^{\mathrm{b}}$ Indian Institute of Remote Sensing, Dehradun, India (debdutt01@gmail.com)
}

KEY WORDS: Phytomass, carbon, sampling, modelling, climate change

\begin{abstract}
:
The aim of this research was to develop an understanding of how mountainous forests function in relation to forest phytomass and carbon accumulation in the terrestrial vegetation pools which will help develop options for climate change. In this study, the forest phytomass has been assessed in range of subtropical and temperate forest dominated by tree species of Quercus semicarpifolia Sm. and Pinus roxburghii Sarg in Himalayan region Purola tehsil in Uttarkashi district of Uttarakhand state of India. In-situ measurements of the phytomass were taken with clustered sampling approach on a total of 40 plots ( 0.1 ha each), i.e. in 10 MODIS pixels with 4 plots laid in an individual pixel. The field measured phytomass was found in the range of $67.76-1,108 \mathrm{t} \mathrm{ha}^{-1}$. Weighted-area phytomass was estimated at an individual MODIS (MOD13Q1, 250m) pixel where in-situ measurements varied from $207.93 \mathrm{tha}^{-1}-1,042 \mathrm{t} \mathrm{ha} \mathrm{a}^{-1}$. The best fit equation of pixel phytomass values was regressed on red, infra-red and vegetation indices (NDVI) derived from the MODIS data. The correlation between the measured phytomass and NDVI was found significant and maximum in the month of December $(\mathrm{R}$ value $-0.71, \mathrm{p}<0.01$ ). However, such a relationship was not persistent throughout the year. The $\mathrm{R}^{2}$ value between observed phytomass and predicted phytomass was 0.53 . The predicted phytomass based on $250 \times 250 \mathrm{~m}$ MODIS data varied from $216.88-1,011 \mathrm{t} \mathrm{ha}^{-1}$. The average phytomass density in study area was $470.42 \mathrm{t} \mathrm{ha}^{-1}$ and carbon density $221.09 \mathrm{tha}^{-1}$
\end{abstract}

\section{INTRODUCTION}

Climate is an important factor for living organisms on earth Due to continuous growth of population, industries and urbanization, forest cover is continuously decreasing and resulting in high negative impact on climate (IPCC, 2007a; Vitousek et.al., 1997; Dadhwal et.al., 2009). Human induced changes are supplementing greenhouse gases and changing the earthôs atmosphere (IPCC, 2003; 2007a). Hindu Kush Himalayan (HKH) forests, which serve a large part of south Asia, are among the most fragile environments on earth. HKH forests are rich repositories of phytomass, biodiversity, water, providers of ecosystem goods and services which many living organisms, both regional and global, depend on (Hamilton, 2002; Korner, 2004; Shrestha et al. 2004; Viviroli and Weingartner, 2004). Phytomass is one of the important indicators for understanding of how forest ecosystems in mountainous region functions and their role in terrestrial vegetation carbon pools and global carbon cycle under climate change (Darke et. al., 2002; Xiao et.al., 1997). Forest phytomass varies widely by types, site conditions, environment, and human interference, natural or planted forests and closed or open forests (Brown et.al., 1991; Naeem and Thompson, 1994). In the recent past, forest phytomass-related studies have become highly significant across the globe due to growing concern of the global warming and forest carbon credit system (Houghton, 1991; Dadhwal et.al., 2009).

Direct measurement of forest phytomass in the field would be a destructive method ( $\mathrm{Lu}, 2005)$, which is not economic in case of old growth forests, especially in the protected and restricted areas. Therefore, the field observations of phytomass are normally based on allometric equations that approximate phytomass of the tree component or the total phytomass of single standing tree according to easily measured variable, such as diameter at breast height (dbh) and tree height (FSI, 1996; $\mathrm{Lu}, 2005$; Whittaker, 1966). However, an initial harvesting of entities over a varied range of size and girth classes may be required for establishing a functional relationship between phytomass and easily measurable plant parameters, such as diameter/ girth and/or height (Kale et.al., 2004; Kale and Roy, 2012; Patil et.al., 2012; Tiwari, 1994). Non-destructive approach involves application of component-wise equations for different species, through sampling of tree components like bole, branch, twigs and leaves (Tiwari, 1994). In the last couple of decades, satellite remote sensing has been successfully used for phytomass and productivity estimation at local and regional level (Foody et.al., 2003; Muukkonen and Heiskanen, 2007; Patil et.al., 2012; Prince and Goward, 1995). There are three main approaches for phytomass assessment viz., ground measurements, remote sensing and geographic information system (Lu, 2005). The wide arrays of earth observation systems have opened a number of opportunities for quick and consistent assessments for monitoring above ground standing phytomass and carbon pools. Recently many efforts have been made to take full advantage of high, medium and coarse resolution remote sensing data in assessing vegetation phytomass and carbon (Kale et.al., 2004; Kale and Roy, 2012; Patil et.al., 2012; Tiwari, 1994). A vegetation index, particularly NDVI, is a good indicator of canopy cover, which in turn is positively correlated to phytomass and productivity (Kale et al., 2002; Patil et.al., 2012; Prince and Goward, 1995). Using satellite data and field measurements, this study primarily aims to estimate the phytomass and carbon pools in selected study area of HKH forests in Himalayan region in Purola tehsil of Uttarkashi district Uttarakhand state in India. The other important objective was to develop spectral models to produce geospatial distribution of forest phytomass and carbon stock in the study area. 


\section{MATERIALS AND METHODS}

\subsection{Study Area}

The study area, located in Purola tehsil of Uttarkashi district of Uttarakhand state, is situated within $31^{\circ} 00^{\prime}$ to $31^{\circ} 16^{\prime} \mathrm{N}$ latitude and $78^{\circ} 00^{\prime}$ to $78^{\circ} 38^{\prime}$ E longitude (Fig. 1). An area of $10 \times 10$ $\mathrm{km}$ was selected and representative field plots were laid. The area is mountainous and its altitude varied from $1200-6387 \mathrm{~m}$ asl. The climate of this area varies from subtropical monsoonal at lower elevations to temperate and alpine at higher elevations. Substantial area remains covered with snow and glaciers most of the year. Annually the rainfall varies from 1000 to $1500 \mathrm{~mm}$. Heavy snowfall occurs during the winter. The spring season (mid-March to mid-June) is characterized by occasional showers of rain and is sometimes accompanied with thunder storms and hail. The highest rainfall occurs during July and August. Snowfall occurs in the upper reaches as early as September but generally it takes place after mid-December. Strong winds are not common in the area. However, high and exposed ridges do experience strong winds at times. Dominant tree species are Pinus roxburghii, Picea smithiana and Quercus leucotrichophora.

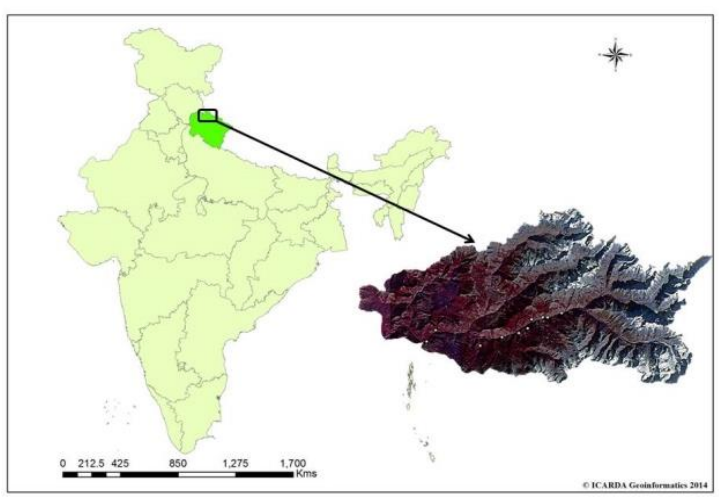

Figure 1. Location of the study area

\subsection{Description of MODIS Data}

Six scenes of 8-day composite satellite images of MODIS Surface Reflectance Product (MOD09Q1) were downloaded from GLCF site (http://glcf.umiacs.umd.edu/data/ modis/) for the months of February, March, May, October, November and December in 2007 having spatial resolution of $250 \mathrm{~m}$ in band 1 and band 2. In addition, forest density map for the study region was procured from Forest Survey of India (FSI, 2003).

\subsection{In-situ Measurements}

Ground sampling was conducted for mapping vegetation cover type and density. Two stage nested clustering approach was followed for collecting the in-situ data. Four sample plots of 0.1 ha were laid within an area of $250 \times 250 \mathrm{~m}$, which is equivalent to the size of one pixel of MODIS 250m (Dadwal et.al., 2009; Patil et.al., 2012). A total of 40 sampled plots at 10 sites of different forest types, topography or aspects were laid out. The phytomass parameters such as $\mathrm{dbh}(\mathrm{cm})$ at $1.37 \mathrm{~m}$ above ground and tree height $(\mathrm{cm})$, compositions, density, percent canopy covered were recorded for each sampling units.
A standard conventional nondestructive method was followed to estimate phytomass (Dadhwal et.al., 2009; Patil et.al., 2012). This method involves estimation of phytomass of individual trees using allometric equations using dbh and height of the trees. The site and species-specific allometric equations for Uttarkashi and adjacent areas were gathered from the literature (Rana, 1985; Rana et.al., 1989). A total number of 12 allometric equations of trees were found. The phytomass of each of the four components, bole, branch, twig and leaf, was estimated by using allometric equation. The phytomass of all trees within a plot was aggregated and total plot phytomass estimated. Mean site phytomass was obtained by taking mean phytomass of the four plots at each site. The overall methodology is given below (Fig. 2).

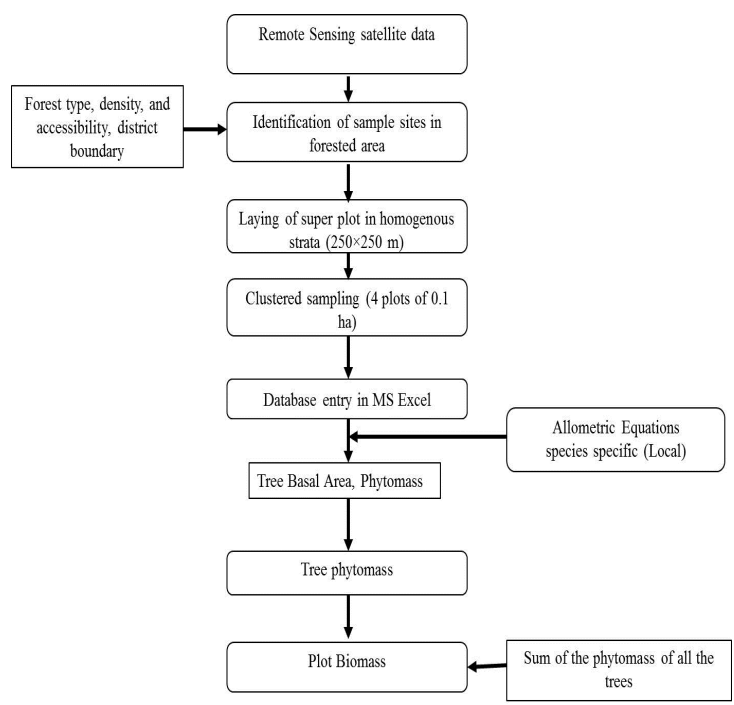

Figure 2. Flow chart showing the broad steps for phytomass estimation

\subsection{Weighted Area Phytomass Estimation}

MODIS data was used to create vector-boxes around the 10 sampling sites in GIS domain. These vector-boxes of $250 \times 250$ $\mathrm{m}$ were then overlaid on density map. Visual interpretation of data within each vector-box for mapping for vegetation cover type/ land use and density was carried out using field points. Proportionate area of each land use/land cover occurring within the vector boundary was obtained by getting the ratio between the area occupied by the respective land-use/cover class within the pixel and total area of the MODIS pixel i.e. $6.25 \mathrm{ha}^{-1}$. The classes such as water body and settlement were given zero weight. The forested area was multiplied by respective phytomass to obtain total phytomass for that type for that area. Subsequently, area weight of each land use/ land cover classes were multiplied with the corresponding phytomass of the respective class. Thus phytomass obtained for all the vegetation types belonging to different forest type-wise density classes occurring within the vector boundary of $250 \times 250 \mathrm{~m}$ area was summed up to get weighted phytomass $\left(\mathrm{t} \mathrm{ha}^{-1}\right)$ within the respective pixels. Area weighted phytomass was obtained for each sample site (Fig. 3).

\subsection{Phytomass Estimation}




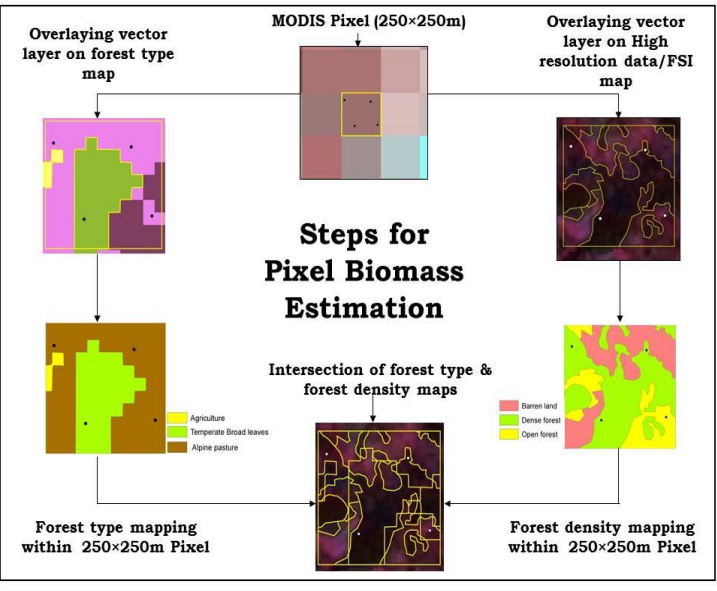

Figure 3. Steps followed in estimating the phytomass at pixel level.

\subsection{Spectral Modeling}

Spectral modeling was carried out for the mapping of phytomass and up-scaling of plot observations into regional scale by correlating it with reflectance of multi-season MODIS data. Correlation coefficients were obtained for phytomass estimation as a function of satellite derived parameters viz., red and infrared reflectance and NDVI. In the spectral modeling, multi-season images of February, May, October and December months were used for establishment of correlation between area weighted phytomass and satellite derived parameters. Statistical models such as linear and nonlinear, i.e., logarithmic, exponential and power functions, to relate phytomass to the data from different bands and indices (Red, Infrared and NDVI) were obtained. The best fit model was selected on the basis of high $\mathrm{R}^{2}$ values (also called coefficient of determination) and its significance. The best fit model thus obtained was used to estimate phytomass and carbon for the entire study area. Carbon content in vegetation was taken as 47 per cent of the above ground phytomass as followed in the National Carbon Project (Dadhwal et.al., 2009, Patil et.al., 2012). The overall methodology adopted for the spectral modeling for present study has been depicted (Fig. 4).

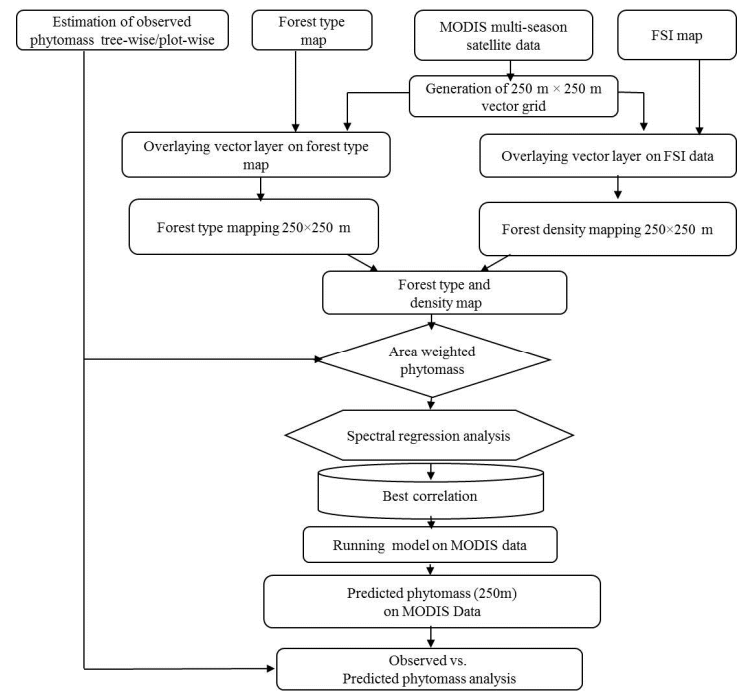

Figure 4. Steps followed spectral modeling of phytomass

\section{RESULTS AND DISCUSSION}

\subsection{Phytomass Based on Field Measurements}

Field measured phytomass ranged between $67.77-1,108 \mathrm{t}$ ha $^{-1}$ in different vegetation types in the mountainous forests in the region. The lowest phytomass range $67.77-386.53 \mathrm{t} \mathrm{ha}^{-1}$ occurred in mixed conifer forests. In the alpine pastures, pytomass was $415.1-556.97 \mathrm{t} \mathrm{ha}^{-1}$ while in temperate broad leaves forest, pytomass varied from $397.5-1,108 \mathrm{tha}^{-1}$. These estimates are within the range reported for the phytomass estimates for certain Himalayan forests. Rana et.al., (1989) estimated phytomass in the central Himalayas as $199-787 \mathrm{t}$ ha ${ }^{1}$, where the tree species were Shorea robusta Gaertn.F., Pinus roxburghii, Quercus leucotrichophora and mixed oak (Quercus $s p$.). Sundriyal et.al., (1996) estimated phytomass in eastern Himalaya about $368-682 \mathrm{t} \mathrm{ha}^{-1}$. In central Himalaya, Garkoti and Singh, (2009) estimated phytomass in the range $40-308 \mathrm{t}$ $\mathrm{ha}^{-1}$. In the present case, within 4 plots at a one site in temperate broad leaves forest, phytomass in this site was found up to $1,108 \mathrm{tha}^{-1}$ which is higher than the comparable estimates reported in different earlier studies.

\subsection{Regression Analysis of Phytomass and Satellite Derived Parameters}

Regression analysis of observed phytomass in weighted area phytomass of 10 sampling sites were evaluated with multiseason MODIS SR data using linear, power, exponential and logarithmic functions. Highest correlation was observed between weighted area phytomass and NDVI data of December month with logarithmic function $\left(\mathrm{R}={ }^{-} 0.71\right)$ followed by IR band $\left(R^{2}=0.26\right)$ in May month with linear function and Red band with logarithmic function $\left(R^{2}=0.12\right)$. Therefore, the model based on NDVI data of December month with logarithmic function was used for modeling of phytomass in the area.

The logarithmic regression model with NDVI $(x)$ gave the equation, $\mathrm{Y}=-267.85 * \ln (\mathrm{x})+302.18$ with $\mathrm{R}$ of -0.71 and residual standard deviation $(\mathrm{SD})= \pm 231.79$ with 8 degrees of freedom (Fig. 5).

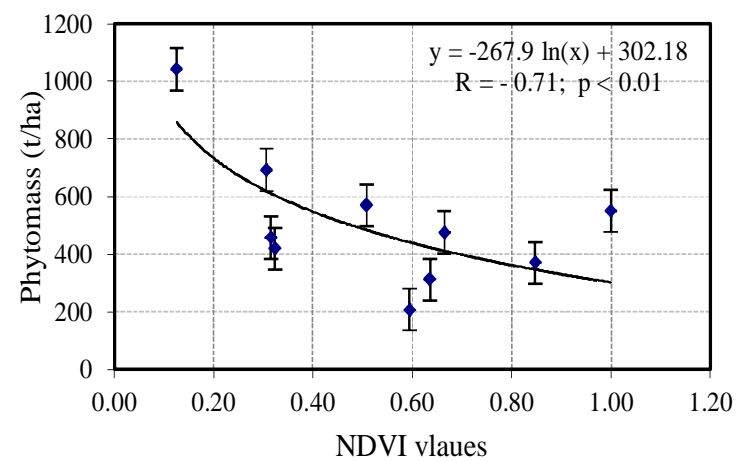

Figure 5. Regression of field based phytomass estimate $\left(\mathrm{t} \mathrm{ha}^{-1}\right)$ on December month NDVI (x)

This model has been used to find the extrapolated predicted phytomass (Fig. 6). Agriculture, water bodies and settlements were not considered for estimating predicted phytomass and masked out. 


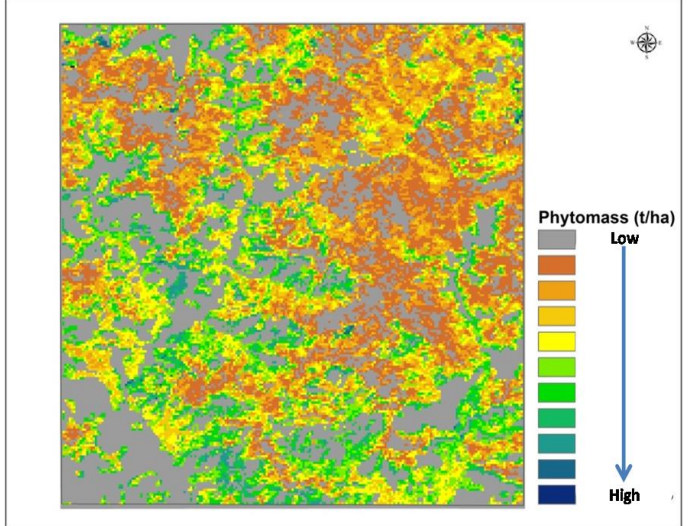

Figure 6. Satellite derived phytomass map of $250 \mathrm{~m}$ resolution

\subsection{Predicted versus Estimated Phytomass}

A comparative assessment was made to estimate regression of the estimated phytomass, i.e., field based phytomass estimate using sample observations $(\mathrm{N}=10)$ on the predicted phytomass obtained through spectral modeling. The squared correlation between observed and estimated phytomass, $\mathrm{R}^{2}$, was 0.53 . Predicted phytomass varied from $216.9-1011 \mathrm{t} \mathrm{ha}^{-1}$. The average phytomass density in the study area was $470.4 \mathrm{t} \mathrm{ha}^{-1}$ and the average carbon density $221.1 \mathrm{t} \mathrm{ha}^{-1}$. The major contributors to the difference between predicted and estimated phytomass values were due to density and phenological conditions of the trees or forest types existing in the study area.

\section{CONCLUSIONS}

In this study, we observed a very large quantity of ground measured phytomass $\left(1,108 \mathrm{t} \mathrm{ha}^{-1}\right)$, within 4 plots at one site in temperate broad leaves forest. This estimate is larger than those reported in comparative studies. At this site, we noted that the trees were of very large size and the forest patch was undisturbed. On excluding the 4 plots at this, phytomass estimates were found within the range given in earlier reports. The observed negative correlation $(\mathrm{R}=-0.71)$, may be due to the dynamics of leaves (LAI and chlorophyll) in relation with phytomass. Since NDVI is highly associated with chlorophyllian activity, which characterizes the photosynthesis process, rather than phytomass. Therefore, an old mature forest will have lower NDVI values than that of earlier stages of the succession when a stronger growth gives a stronger NDVI basically. When the forest gets mature in a stable environment, the mean annual NDVI should become relatively constant at some point. When a forest grows further old, the carbon dynamics goes towards equilibrium between its uptake and release at the ecosystem level. Thus a full grown natural forest releases as much carbon dioxide as it takes up on a yearly basis, both for tropical as well as non-tropical forest ecosystems. It is pertinent to observe that the NDVI is not correlated with wood and trunk phytomass of a forest, but only with the dynamics of its green leaves.

Furthermore, in case of dense and humid rainforests, NDVI has to be used with caution because the index saturates on such areas. We observed that majority of the trees were old and large in size, and were infested with trunk rot or hollow trunk. Dealing with the hollow trunk is still a challenging area of active research in forest carbon dynamics.
Authors are thankful to Dr. Manish Kale for his valuable comments and suggestions which overall improved the quality of the presentation. First author is also thankful to Dr. V. K. Dadhwal, Director National Carbon Project (ISRO-GBP) and Head of Forestry and Ecology Division, Indian Institute of Remote Sensing, Dehradun, for sharing ground data collected under the Vegetation Carbon Pool project for this case study.

\section{REFERENCES}

Brown, S., Gillespie, A. J. R., \& Lugo, A. E., 1991. Phytomass of tropical forests of south and Southeast Asia. Canadian Journal of Forest Research, 21, pp. 111-117.

Dadhwal, V. K., Singh, S., \& Patil, P., 2009. Assessment of phytomass carbon pools in forest ecosystems in India. NNRMS Bulletin, pp. 41-47.

Drake, J. B., Dubayah, R. O., Clark, D. B., Knox R. G., Blair, J. B., Hofton, M. A., Chazdon, R. L., Weishampel, J. F., \& Prince, S., 2002. Estimation of tropical forest structural characteristics using large-footprint lidar. Remote Sensing of Environment, 79, pp. 305-319.

Foody, G. M., Boyd, D. S., \& Cutler, M. E. J., 2003. Predictive relations of tropical forest phytomass from Landsat TM data and their transferability between regions. Remote Sensing of Environment, 85, pp. $463 \mathrm{I} 474$.

FSI., 1996. Volume Equations for Forester of India, Nepal and Bhutan. Ministry of Environment and Forests, Government of India, Dehradun. pp. 1-249.

Garkoti, S. C. \& Singh, S. P., 2009. Variations in the Net primary productivity and biomass of forests in high altitude region in the central Himalayan region. Journal of Vegetation Science, 1, pp. 23-28.

Hamilton, L. S., 2002. óWhy mountain matters?ôWorld Conservation: The IUCN Bulletin.

Hughton, R. A., 1991. Tropical deforestation and atmospheric carbon dioxide. Climate Change, 19, pp. 99-118.

IPCC., 2007a. Climate change: The physical science basis. Contribution of Working Group I to the Fourth Assessment Report of the Intergovernmental Panel on Climate Change [Solomon, S; Qin, D; Manning, M; Chen, Z; Marquis, M; Averyt, KB; Tignor, M; Miller, HL (eds)]. Cambridge and New York: Cambridge University Press.

Kale, M. S., Singh \& Roy, P. S., 2002. Biomass and productivity estimation using aerospace data and geographic Information System. Tropical Ecology, 43, pp. 123-136.

Kale, M., Singh, S., Roy, P. S., Deosthali, V., \& Ghole, V. S., 2004. Biomass equations of dominant species of dry deciduous forest in Shivpuri district, Madhya Pradesh. Current Science, 87 , pp. 683-687.

Kale, M., \& Roy, P. S., 2012. Net primary productivity estimation and its relationship with tree diversity for tropical dry deciduous forests of central India. Biodiversity and Conservation, 21, pp. 1199101214.

\section{ACKNOWLEDGEMENTS}


Korner, C., 2004. Mountain biodiversity, its causes and function. Ambio Supplement, 13, pp.11-17.

Lu, D., 2005. Aboveground phytomass estimation using Landsat TM data in the Brazilian Amazon, International Journal of Remote Sensing, 26, pp. 2509 ï 2525.

Muukkonen, P., \& Heiskanen, J., 2007. Phytomass estimation over a large area based on stand wise forest inventory data and ASTER and MODIS satellite data: A possibility to verify carbon inventories, Remote Sensing of Environment, 107, pp. $617 \mathrm{i} 624$.

Matsushita, B., \& Masayuki, T., 2002. Integrating remotely sensed data with an ecosystem model to estimate net primary productivity in East Asia. Remote Sensing of Environment, 81, pp. $58 і ̈ 66$.

Miles, L., \& Kapos, V., 2008. Reducing greenhouse gas emissions from deforestation and forest degradation: global land-use implications. Science, 320, pp. 1454 İ 1455.

Naeem, S., \& Thompson, L. J., 1994. Declining biodiversity can alter the performance of ecosystems. Nature, 368, pp. $734 i ̈ 737$.

Patil, P., Singh, S., \& Dadhwal,V. K., 2012. Above ground forest phytomass assessment in Southern Gujarat. Journal of the Indian Society of Remote Sensing, 40, pp. 37-46

Prince, S.D. \& Goward, S. J., 1995. Global Primary Production: A remote sensing approach. Journal of Biogeography, 22, pp. $815 i ̈ 835$.

Rana, B.S., 1985. Biomass \& Net Primary Productivity in Different Forest Ecosystems Along an Altitudinal Gradient in Kumaun Himalaya. Ph.D. Thesis. Kumaun University, Nainital. pp. 35-36.

Rana, B. S., Singh, S. P., \& Singh, R. P., 1989. Biomass and net primary productivity in central Himalayan forests along an altitudinal gradient. Forest Ecology and Management, 27, pp. 199-218.

Shrestha, A.B., 2004. Climate change in Nepal and its impact on Himalayan glaciers. In: Climate hotspots: Key vulnerable regions, climate change and limits to warming, Proceedings of the European Climate Change Forum Symposium. (Hare, WL; Battaglini, A; Cramer, W; Schaeffer, M; Jaeger, C., eds.) . Potsdam: Potsdam Institute for Climate Impact Research.

Sundriyal, R.C., \& E. Sharma., 1996. Anthropogenic pressure on tree structure and biomass in the temperate forest of Mamlay watershed in Sikkim. Forest Ecology and Management, 243, pp. 299-309.

Tiwari, A.K., 1994. Mapping forest phytomass through digital processing of IRS-1A data. International Journal of Remote Sensing, 15(9), pp. 1849-1866.

Vitousek, P. M., Mooney, H. A., Lubchenco, J. \& Melillo J. M., 1997. Human domination of earthôs ecosystems, Science, 277, pp. 494-499.

Viviroli, D. \& Weingartner, R., 2004. Hydrological significance of mountains: From regional to global scale. Hydrological Earth Systems Science, 8(6), pp. 1016-1029.

Whittaker, R. H., 1966. Forest dimensions and production in the great smoky mountains. Ecology, 47(1), 103-121.

Xiao, X., Kicklighter, D. W., Melillo, J. M., McGuire, A. D., Stone, P. H., \& Sokolov, A. P., 1997. Linking a global terrestrial biogeochemical model and a 2-dimensional climate model: Implications for the global carbon budget. Tellus Series B-Chemical and Physical Meteorology, 49, pp. 18-37. 